\title{
Perancangan Aplikasi Rencana Anggaran Biaya Pada PT. Zaki Putra Andalas Jambi
}

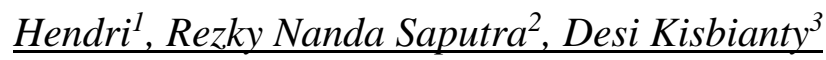 \\ Program Studi Teknik Informatika, STIKOM Dinamika Bangsa, Jambi \\ Jl. Jendral Sudirman, Thehok-Jambi, Telp. 0741-35095/Fax. 0741-35093 \\ E-mail: hendri@stikom-db.ac.id ${ }^{1}$,rezkyekie.gps@gmail.com ${ }^{2}$,desikisbianty@stikom-db.ac.id ${ }^{3}$
}

\begin{abstract}
PT. Zaki Putra Andalas is a building construction company in Jambi. Processing the budget plan at this company is still using Microsoft Excel, the estimation process for the analysis of materials and wages takes quite a long time. Employees find it difficult to search material and wage data because there is too much data and it takes time to access it, which results in time for completion of the budget plan and even frequent errors. This study aims to provide a solution by offering a budget plan application using the PHP programming language and MySQL database so that data processing is more structured and can provide the required information quickly and precisely. This study uses the waterfall system development method and system modeling using use case diagrams and flowcharts. The resulting application can provide information in the form of employment data, customer data, material and wage analysis data and budget plan reports.
\end{abstract}

Keywords : Application, Material and Wage Calculation, Budget Plan

\begin{abstract}
Abstrak
PT. Zaki Putra Andalas merupakan salah satu perusahaan konstruksi bangunan di Jambi. Pengolahan rencana anggaran biaya di perusahaan ini masih menggunakan Microsoft Excel, proses estimasi untuk analisa bahan dan upah membutuhkan waktu cukup lama. Karyawan kesulitan untuk melakukan pencarian data bahan dan upah dikarenakan data yang terlalu banyak dan membutuhkan waktu untuk mengaksesnya sehingga berdampak waktu penyelesaian rencana anggaran biaya dan bahkan sering terjadi kesalahan. Penelitian ini bertujuan memberikan solusi dengan menawarkan aplikasi rencana anggaran biaya menggunakan bahasa pemograman PHP dan database MySQL sehingga pengolahan data lebih terstruktur dan dapat memberikan informasi yang dibutuhkan secara cepat dan tepat. Penelitian ini menggunakan metode pengembangan sistem waterfall dan pemodelan sistem menggunakan use case diagram dan flowchart. Aplikasi yang dihasilkan dapat menyediakan informasi berupa data pekerjaan, data pelanggan, data analisa bahan dan upah dan laporan rencana anggaran biaya.
\end{abstract}

Kata Kunci : Aplikasi, Perhitungan Bahan dan Upah, Rencana Anggaran Biaya

(C) 2019 Jurnal Ilmiah MEDIA SISFO

\section{Pendahuluan}

Teknologi yang berkembang sesuai tuntutan zaman menjadi sarana yang sangat mendukung untuk menangani berbagai permasalahan yang timbul dalam mengelola dan menyelesaikan permasalahan yang ada di perusahaan, instansi maupun organisasi lain. Rencana Anggaran Biaya (RAB) merupakan salah satu proses utama dalam suatu proyek karena merupakan dasar untuk membuat estimasi biaya yang akan dikeluarkan. RAB adalah pedoman untuk persiapan budget agar pembangunan tidak terhenti di tengah jalan [1].Rencana anggaran biaya diperlukan untuk memperhitungkan suatu bangunan atau proyek dengan banyaknya biaya yang diperlukan untuk bahan dan upah, serta biaya - biaya lain yang berhubungan dengan pelaksanaan bangunan atau proyek.

RAB proyek bangunan gedung disusun seoptimal dan seefisien mungkin dengan mutu dan kwalitas yang tetap terjamin [2]. Untuk itu diperlukan perhitungan-perhitungan yang teliti. Baik dari jumlah biaya pembuatannya, volume pekerjaan, jenis pekerjaan, dan harga bahan. Semua itu bertujuan untuk mengetahui biaya pembuatan rumah sehingga lebih efisien dan terukur sesuai dengan keinginan pemilik dalam membangun rumah. Analisa anggaran dan jadwal merupakan dua hal penting dalam pelaksanaan 
pekerjaan konstruksi selain mutu, karena biaya yang akan dikeluarkan pada saat pelaksanaan sangat erat kaitannya dengan waktu pelaksanaan pekerjaan.[3]

PT. Zaki Putra Andalas Jambi membuat RAB masih menggunakan microsoft excel, sehingga mengalami beberapa kendala seperti : proses estimasi dan pengumpulan data untuk bahan dan upah yang diambil dari nota dan biaya yang dikeluarkan membutuhkan waktu yang cukup lama, perhitungan estimasti untuk analisa bahan dan upah sering terjadi kesalahan sehingga RAB yang dibentuk tidak sesuai dengan harapan yang dapat menyebabkan terjadinya kerugian di pihak perusahaan, dan pembuatan laporan RAB yang memakan waktu cukup lama dan sering terjadinya kesalahan dalam perhitungan. Oleh karena itu dibutuhkan aplikasi untuk menghitung secara cepat dan tepat RAB suatu pekerjaan pembangunan rumah sehingga hasil dari aplikasi dapat memudahkan perusahaan dalam pengelolaan data RAB. Penggunaan program aplikasi akan sangat membantu meningkatkan efektivitas dan efisiensi pelaksanaan kegiatan anggaran belanja yang akan menghasilkan informasi yang cepat dan akurat serta relevan [4].

Penelitian ini bertujuan menganalisis sistem perhitungan RAB dan merancang sistem informasi RAB pada PT. Zaki Putra Andalas Jambi dengan menggunakan bahasa pemograman PHP dan database MySQL

\section{Tinjauan Pustaka}

\subsection{Database}

Database merupakan kumpulan dari item data (file atau tabel) yang saling berhubungan satu dengan yang lainnya yang diorganisasikan berdasarkan sebuah skema atau struktur tertentu, tersimpan dalam perangkat keras komputer, dan digunakan perangkat lunak untuk memanipulasinya [5].

\subsection{Rencana Anggaran Biaya}

RAB merupakan perhitungan banyaknya biaya yang diperlukan untuk bahan dan upah, serta biaya-biaya lain yang berhubungan dengan pelaksanaan proyek pembangunan [6]. Fungsi utama dari RAB pendirian bangunan adalah sebagai berikut

1. RAB sebagai penetap jumlah biaya masing-masing bidang pekerjaan pada proses pendirian suatu bangunan. RAB memuat biaya-biaya secara terperinci yang meliputi pengadaan bahan bangunan, upah pekerja, serta biaya lain-lain seperti biaya perijinan dan biaya sarana prasarana.

2. RAB sebagai penentu total kebutuhan material bahan bangunan yang diperlukan. Penghitungan kebutuhan material ini didasarkan pada pengukuran volume pembuatan struktur bangunan.

3. RAB sebagai dasar pemilihan tenaga kerja yang digunakan. RAB menggambarkan pekerjaanpekerjaan konstruksi yang akan dilakukan dan tenaga kerja yang dibutuhkan untuk melakukan pekerjaan tersebut.

4. RAB sebagai penentu peralatan yang dipakai untuk mendukung kelancaran pembangunan konstruksi. RAB juga memutuskan apakah peralatan tersebut perlu dibeli atau cukup disewa.

5. RAB sebagai pemantau penghematan kegiatan pelaksanaan pembangunan. Dari RAB juga dapat diketahui model pengeluaran anggaran biaya yang menghasilkan keuntungan. [6]

\subsection{Penelitian Sejenis}

Penelitian sejenis merupakan review dari beberapa jurnal yang membantu penulis untuk membuat sistem yang akan dirancang dan juga memberikan bahan untuk perbandingan.

Tabel 1. Tabel perbandingan penelitian sejenis

\begin{tabular}{cll}
\hline No. & \multicolumn{1}{c}{ Judul / Penulis } & \multicolumn{1}{c}{ Kesimpulan } \\
\hline 1. & Sistem Informasi Rencana & Aplikasi sistem informasi pembuatan rencana anggaran biaya \\
& Anggaran $\quad$ Biaya & (RAB) Jaringan Terdistribusi (Menengah, Rendah, Gardu) Pada \\
& Pembangunan Jaringan & PT. Cipta Aparta dapat difungsikan sebagai media pengentrian, \\
& Terdistribusi Pada PT. & pengolahan, perancangan data, dan penyimpanan. Pencarian \\
& Cipta Aparta / Rahmadini & data jenis konstruksi dapat ditampilkan berdasarkan kode jenis \\
& Darwas dan Riza Vitriani & konstruksi, dan dapat ditampilkan data rinci konstruksi yang \\
& & berhubungan dengan paket lelang yang ada [7]. \\
\hline 2. & Model Sistem Informasi & Sistem Informasi Pencatatan Pembangunan ini dapat membantu \\
& Pencatatan & admin kontraktor CV. Hamba dalam mengelola data pencatatan \\
& Pengembangan Bangunan & pembangunan, dapat membantu dalam pembuatan RAB atau \\
\hline
\end{tabular}




\begin{tabular}{|c|c|c|}
\hline & $\begin{array}{l}\text { Gedung / } \\
\text { Rahmat Fajri dan Rintana } \\
\text { Arni }\end{array}$ & $\begin{array}{l}\text { rencana anggaran biaya, sampai dengan pemberian bobot rab } \\
\text { hingga melakukan pencatatan pembangunan, dapat membantu } \\
\text { pembuatan pelaporan yang cepat dan tepat [8]. }\end{array}$ \\
\hline 3. & $\begin{array}{l}\text { Perancangan Aplikasi } \\
\text { Rencangan Anggaran } \\
\text { Biaya (RAB) } \text { (Studi } \\
\text { Kasus Pada Dinas } \\
\text { Pekerjaan Umum } \\
\text { Salatiga) / Adi Nugroho, } \\
\text { Yos Richard Beeh, dan } \\
\text { Hettyca Astuningdyas }\end{array}$ & $\begin{array}{l}\text { Perancangan aplikasi yang mampu menjabarkan RAB untuk } \\
\text { pembangunan dan peme- liharaan/rehabilitasi gedung menjadi } \\
\text { daftar kebutuhan material dan tenaga dengan teliti, cepat, akurat, } \\
\text { dan cermat dapat diwujudkan dengan perangkat lunak yang } \\
\text { dibuat menggunakan bahasa pemrograman Java dan } \\
\text { menggunakan Hibernate sebagai tool ORM (Object Relational } \\
\text { Mapping), serta MySQL sebagai server basis datanya [9]. }\end{array}$ \\
\hline 4. & $\begin{array}{l}\text { Rancang Bangun Aplikasi } \\
\text { Rencana Anggaran Biaya } \\
\text { Dalam Pembangunan } \\
\text { Rumah / Achil Yoga Adi } \\
\text { Firmansyah, Arifin Puji } \\
\text { Widodo dan Anjik } \\
\text { Sukmaaji }\end{array}$ & 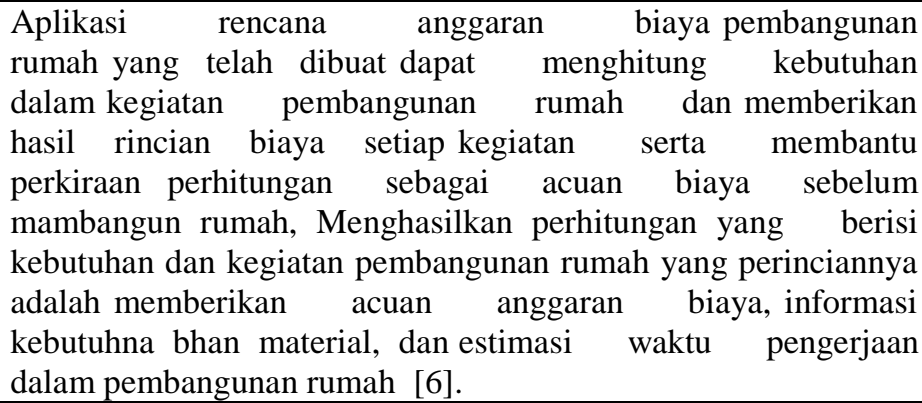 \\
\hline 5. & $\begin{array}{l}\text { Rancang Bangun Aplikasi } \\
\text { Analisis } \\
\text { Realisasi Laporan } \\
\text { Pembangunan Anggaran } \\
\text { Mengacu Pada Standar } \\
\text { Nasional Indoensai Pada } \\
\text { CV. Citra Mandiri } \\
\text { Solution / Moh. Rizal } \\
\text { Hidayat, Arifin Puji } \\
\text { Widodo, dan Ayuningtyas }\end{array}$ & $\begin{array}{l}\text { Penelitian ini telah menghasilkan aplikasi analisis laporan } \\
\text { realisasi anggaran pembangunan gedung yang mengacu pada } \\
\text { SNI dan perlengkapannya (dokumen spesifikasi kebutuhan } \\
\text { perangkat lunak, desain dan testing). Sistem ini dapat membuat } \\
\text { rancangan biaya yang mengacu pada SNI dan menjalankan } \\
\text { proses serta membuat laporan tentang analisis perbandingan } \\
\text { antara LRA dengan RAB, RAB dengan SNI, dan LRA dengan } \\
\text { SNI. Sehingga dari semua informasi yang telah dihasilkan oleh } \\
\text { aplikasi analisis laporan realisasi anggaran tersebut bisa } \\
\text { digunakan sebagai pendukung keputusan dalam perencanaan } \\
\text { proyek selanjutnya [10]. }\end{array}$ \\
\hline
\end{tabular}

\section{Metodologi}

Untuk membantu dalam penyusunan penelitian ini, maka perlu adanya susunan kerangka kerja (frame work) yang jelas tahapan-tahapannya. Kerangka kerja ini merupakan langkah-langkah yang akan dilakukan dalam penyelesaian masalah yang akan dibahas.

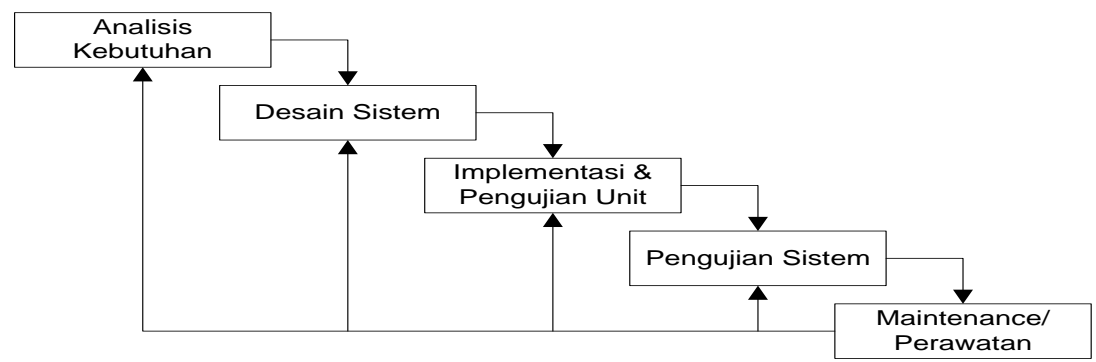

Gambar 1. Model Waterfall

Adapun penjelasan dari metode pengembangan sistem yang terdapat pada Gambar 1 adalah sebagai berikut :

a. Analisis Kebutuhan

Pada tahap ini penulis melakukan analisis kebutuhan secara fungsional dan non fungsional.

Kebutuhan fungsional merupakan kebutuhan akan fungsi-fungsi pada sistem yang akan dirancang yang dilakukan oleh admin, diantaranya login, mengelola data admin, mengelola data pelanggan mengelola data jenis pekerjaan, mengelola data bahan, mengelola data upah, mengelola data analisa, mengelola data uraian pekerjaan, mengelola data analisa bahan dan 
upah, mengelola data pekerjaan, mengelola data rencana anggaran biaya, melihat dan mencetak laporan dan logout. Dan untuk kebutuhan non fungsional, penulis melakukan dari sisi kemudahan pengguna sistem dalam mengakses, informsai yang kelola dan setiap admin diberikan password untuk melakukan login

b. Desain Sistem

Pada tahap ini dilakukan perancangan data, antar muka (interface) dan model sistem dengan menggunakan use case diagram, activity diagram, dan class diagram. Sedangkan untuk merancang prosedur dari sistem menggunakan flowchart. Dan struktur data untuk database

c. Implementasi dan Pengujian Unit

Pada tahap ini sistem yang telah dirancang, diimplementasikan dengan menggunakan program bantu yaitu PHP dan MySQL, kemudian dilakukan pengujian terhadap tiap - tiap unit atau modul yang telah dibuat.

d. Pengujian Sistem

Pada tahap ini dilakukan pengujian menggunakan metode pengujian white box dimana penulis melakukan pengecekan kode - kode program PHP yang ada dan black box dimana penulis melakukan pengecekan hasil keluaran dari aplikasi dan apabila hasil keluar tidak sesuai atau terjadi kesalahan maka penulis melakukan perbaikan agar hasil keluar dari aplikasi sesuai dengan hasil yang diharapkan.

e. Maintenance / Perawatan

Pada tahap ini dilakukan pemeliharaan software seperti melakukan perbaikan - perbaikan terhadap sistem yang berjalan atau menambahkan fungsi tambahan sesuai dengan keinginan pihak PT. Zaki Putra Andalas Jambi

\section{Hasil dan Pembahasan}

\subsection{Analisis Sistem yang Sedang Berjalan}

Analisis sistem yang sedang berjalan merupakan menggambarkan proses bisnis yang terjadi pada perusahaan yaitu PT. Zaki Putra Andalas Jambi yang merupakan kontraktor bangunan, sehingga perusahaan sering membuat RAB untuk setiap pekerjaan proyek. Pengolahan RAB masih menggunakan bantuan microsoft excel dan alat hitung kalkulator untuk analisa bahan dan upah. Proses dalam pembuatan $\mathrm{RAB}$ untuk satu pekerjaan, dapat dilihat pada gambar 2 .

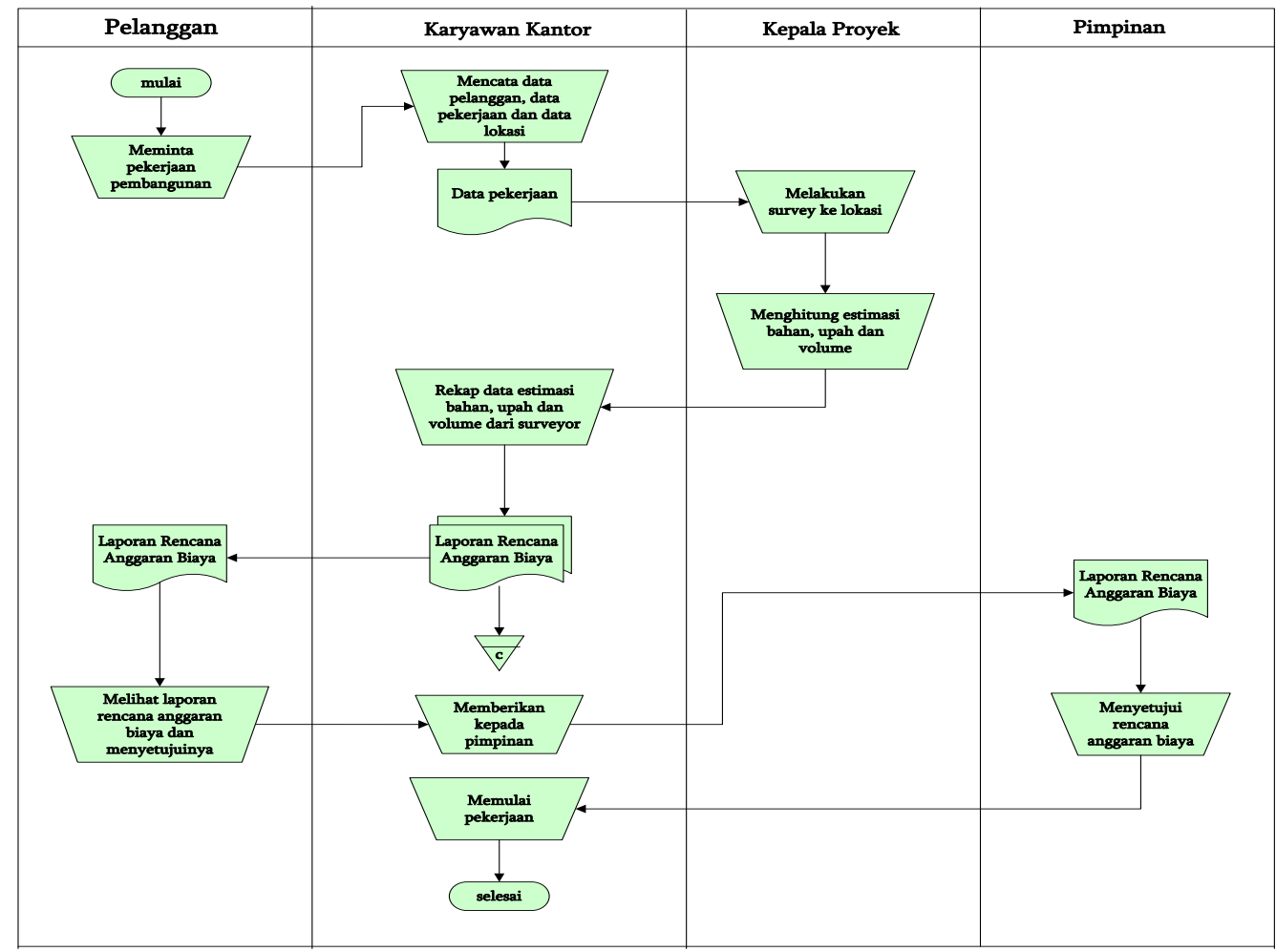

Gambar 2. Flowchart Dokumen Pembuatan RAB 
Setelah mengetahui sistem yang berjalan pada PT. Zaki Putra Andalas Jambi, maka ditemukan beberapa kekurangan, antara lain :

1. Proses estimasi untuk analisa bahan dan upah membutuhkan waktu cukup lama dan sering terjadi kesalahan dalam perhitungan estimasi sehingga RAB menjadi tidak sesuai dengan harapan.

2. Terjadinya kesulitan untuk melakukan pencarian data bahan dan upah dikarenakan data yang terlalu banyak dan membutuhkan waktu dalam pencarian.

3. Dalam pembuatan RAB membutuhkan waktu yang cukup lama dan sering terjadi kesalahan dalam perhitungan sehingga menyebabkan terjadinya kerugian kepada perusahaan.

\subsection{Solusi Pemecahan Masalah}

Berdasarkan analisis permasalahan yang dihadapi, maka penulis merancang solusi pemecahan masalah dengan merancang aplikasi perhitungan RAB dengan fitur yang terdiri dari :

1. Sistem yang dirancang dapat menganalisis bahan dan upah secara terkomputeriasi dengan menginput data bahan dan data upah serta uraian pekerjaan sehingga sistem dapat menghitung estimasi pekerjaan sesuai dengan kebutuhannya

2. Sistem juga dapat melakukan pengolahan data dan pencarian secara terkomputeriasi untuk data jenis pekerjaan, pelanggan, bahan, upah dan pekerjaan yang dilakukan

3. Sistem juga dapat mencetak RAB secara langsung dengan tinggal memilih pekerjaan yang dilakukan dan menampilkan detail volume, harga satuan, dan nilai akhir RAB secara langsung.

\subsection{Pemodelan Sistem}

Berikut ini adalah Use Case Diagram yang dibuat untuk menggambarkan sistem yang baru dimana usecase diagram untuk aplikasi perhitungan RAB pada PT. Zaki Putra Andalas Jambi

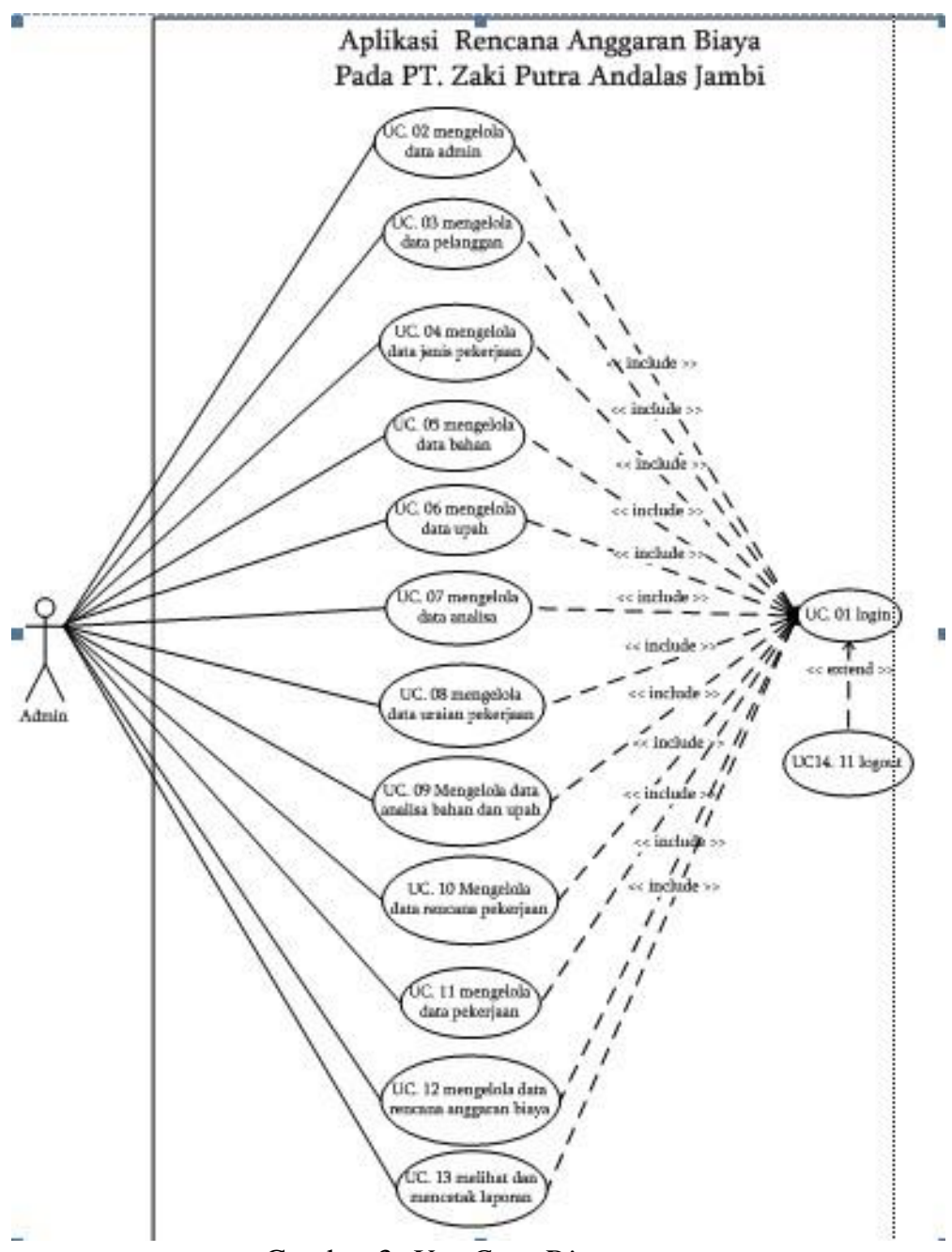

Gambar 3. Use $\bar{C}$ ase Diagram 
Dari gambar 3 diatas terlihat bahwa admin dapat mengelola data pelanggan, jenis pekerjaan, data bahan, upah, rencana pekerjaan dan anggaran biaya.

\subsection{Hasil Implementasi}

Implementasi program digunakan untuk menerapkan perancangan halaman yang ada pada program dimana implementasi ini juga menguji program yang dibuat telah sesuai dengan sistem yang dirancang sehingga program yang dirancang tidak terjadi kesalahan baik dari sisi sistem maupun dari sisi coding sehingga hasil dari program sesuai dengan keinginan dari penulis dan memudahkan penulis untuk melakukan pengecekan dengan program yang telah dibuat apakah telah sesuai dengan keinginan dan dapat memecahkan masalah yang terjadi di PT. Zaki Putra Andalas Jambi.

1. Halaman Login

Halaman login merupakan halaman yang menampilkan kolom nama admin dan password yang digunakan untuk admin dapat masuk ke halaman utamanya.

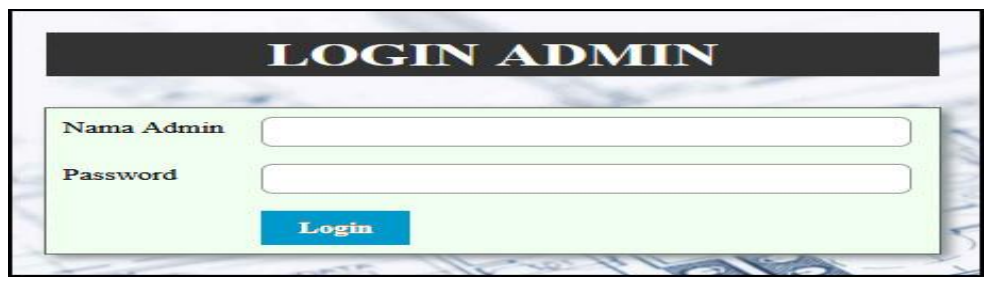

Gambar 4. Login

2. Halaman Data Admin

Halaman data admin merupakan halaman yang menampilkan kolom-kolom untuk menambah data admin baru dan tabel untuk melihat, mengubah dan menghapus data tersebut.

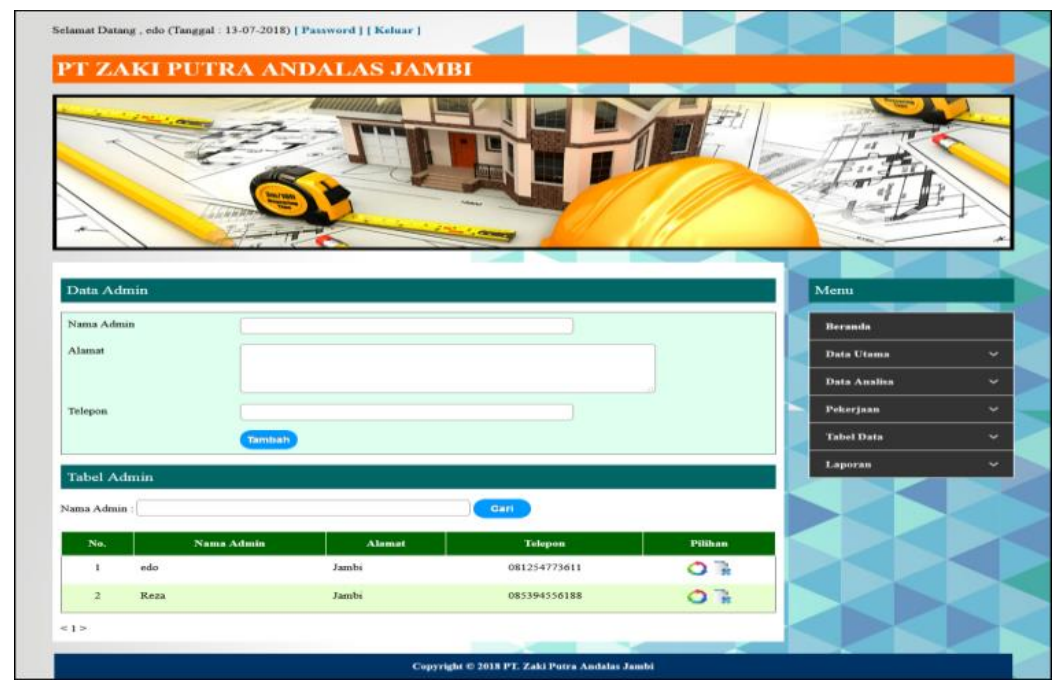

Gambar 5. Data Admin

3. Halaman Data Analisa

Halaman data analisa merupakan halaman yang menampilkan kolom-kolom untuk menambah data analisa baru dan tabel untuk melihat, menghapus data tersebut. 


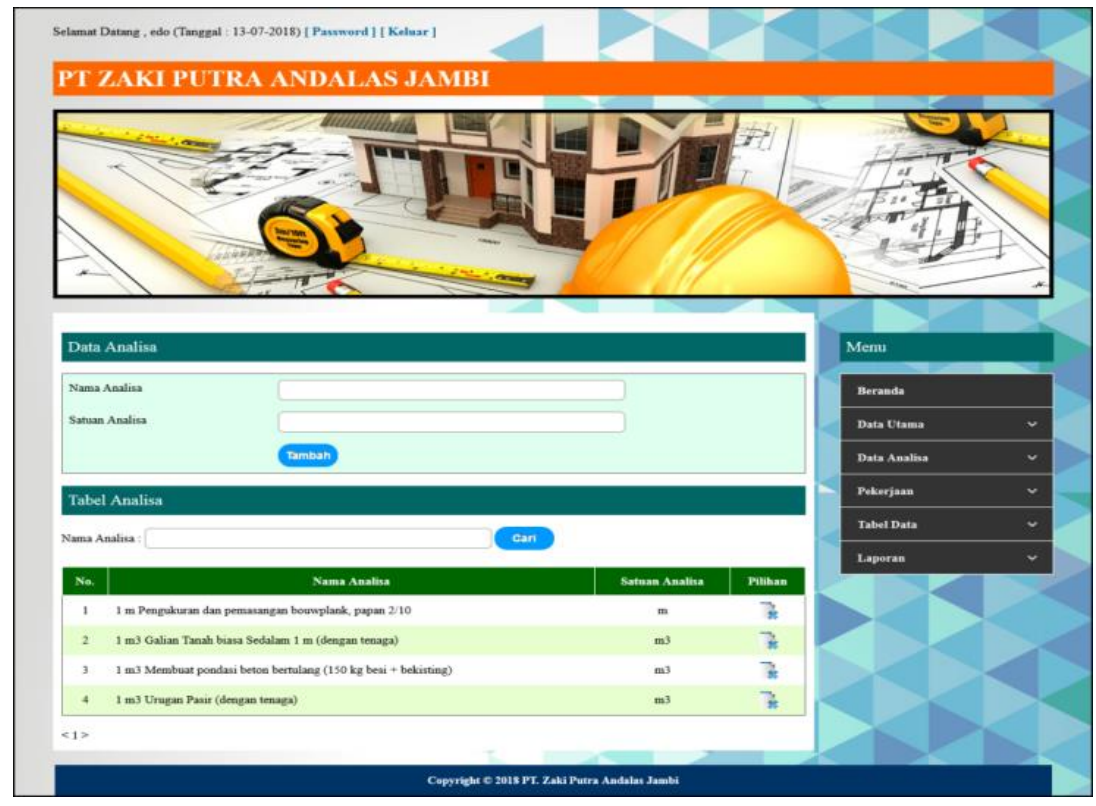

Gambar 6. Data Analisa

4. Halaman Data Uraian Pekerjaan

Halaman data uraian pekerjaan merupakan halaman yang menampilkan kolom-kolom untuk menambah data uraian pekerjaan baru dan tabel untuk melihat, mengubah dan menghapus data tersebut.

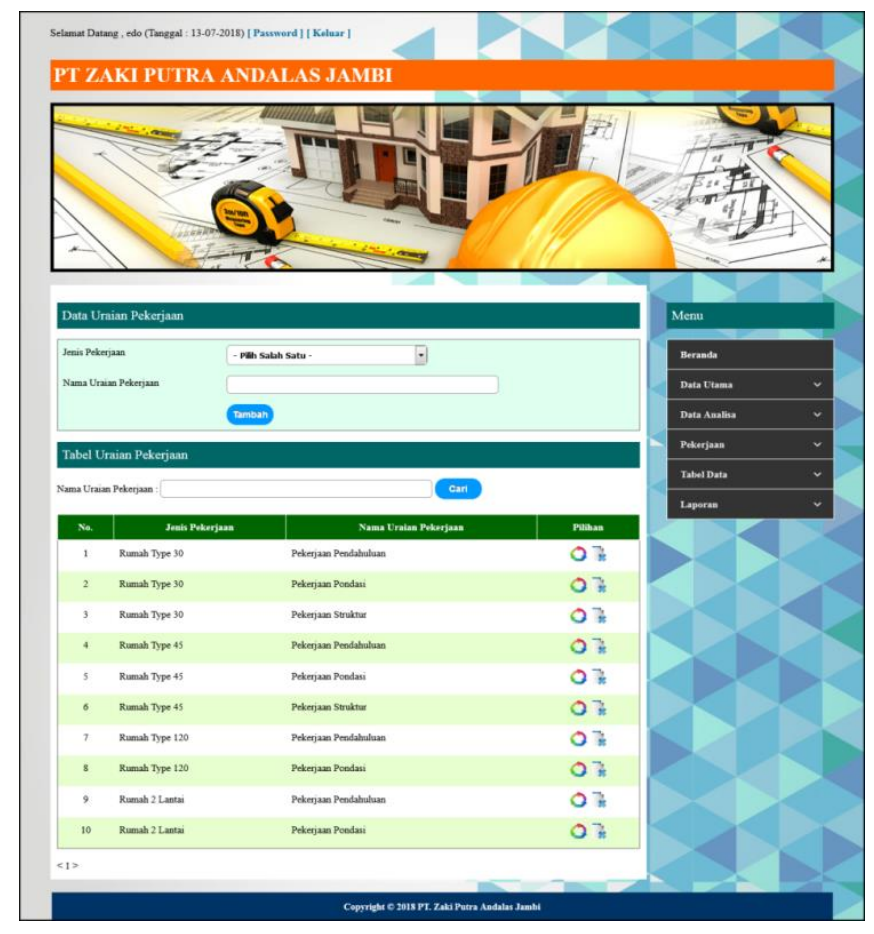

Gambar 7. Data Uraian Pekerjaan

5. Halaman Data Analisa Bahan dan Upah

Halaman data analisa bahan dan upah merupakan halaman yang menampilkan kolom-kolom untuk menambah data bahan dan upah yang baru pada sistem. 


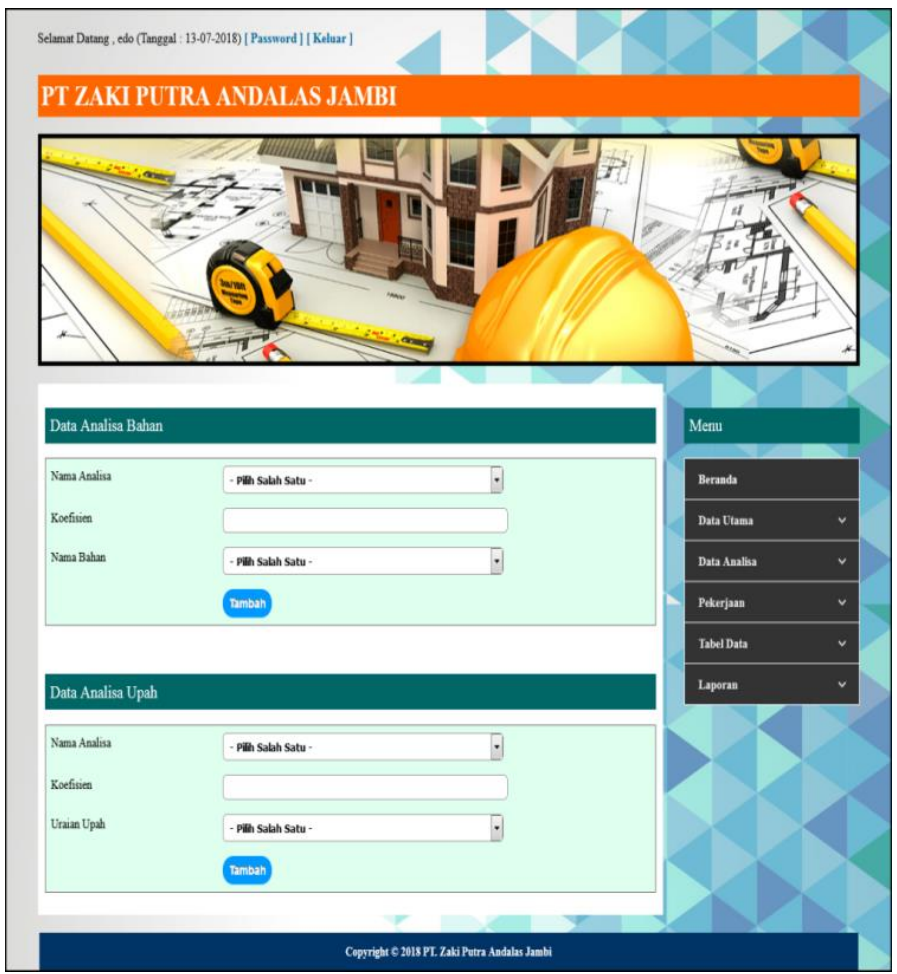

Gambar 8. Data Analisa Bahan dan Upah

6. Halaman Data Rencana Pekerjaan

Halaman data rencana pekerjaan merupakan halaman yang menampilkan kolom-kolom untuk menambah data rencana pekerjaan yang baru pada sistem.

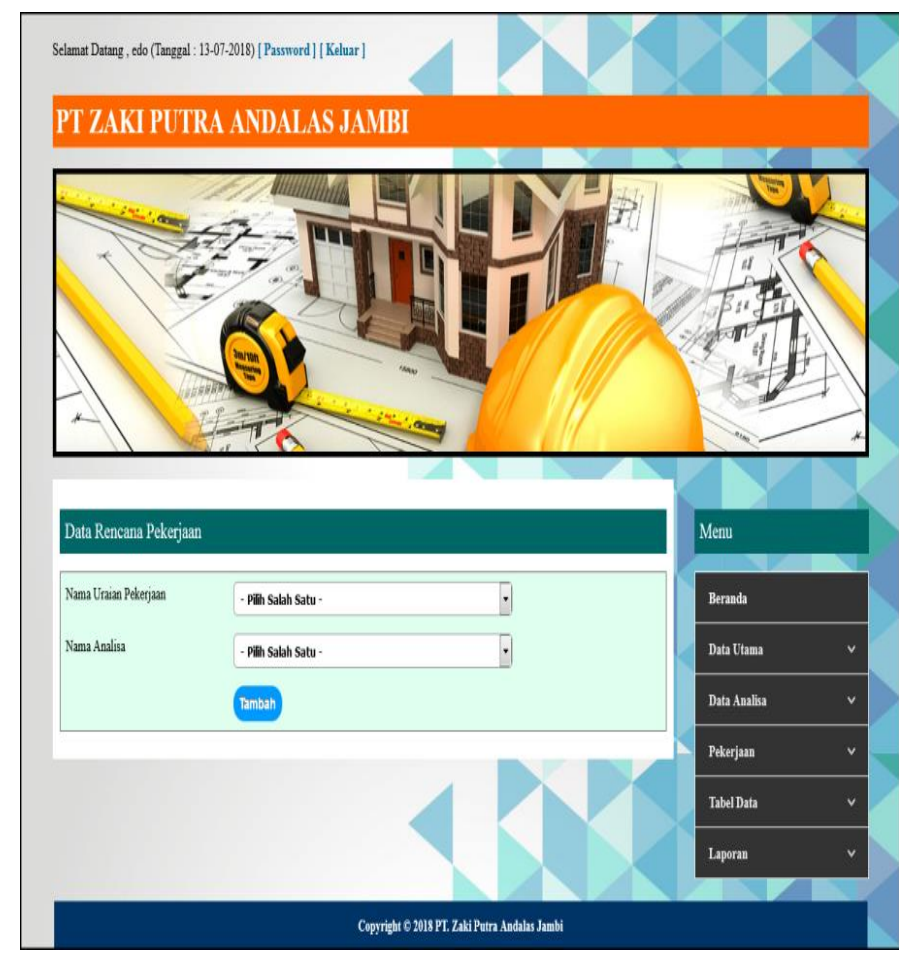

Gambar 9. Data Rencana Pekerjaan 
7. Halaman Data Pekerjaan

Halaman data pekerjaan merupakan halaman yang menampilkan kolom-kolom untuk menambah data pekerjaan yang baru pada sistem.

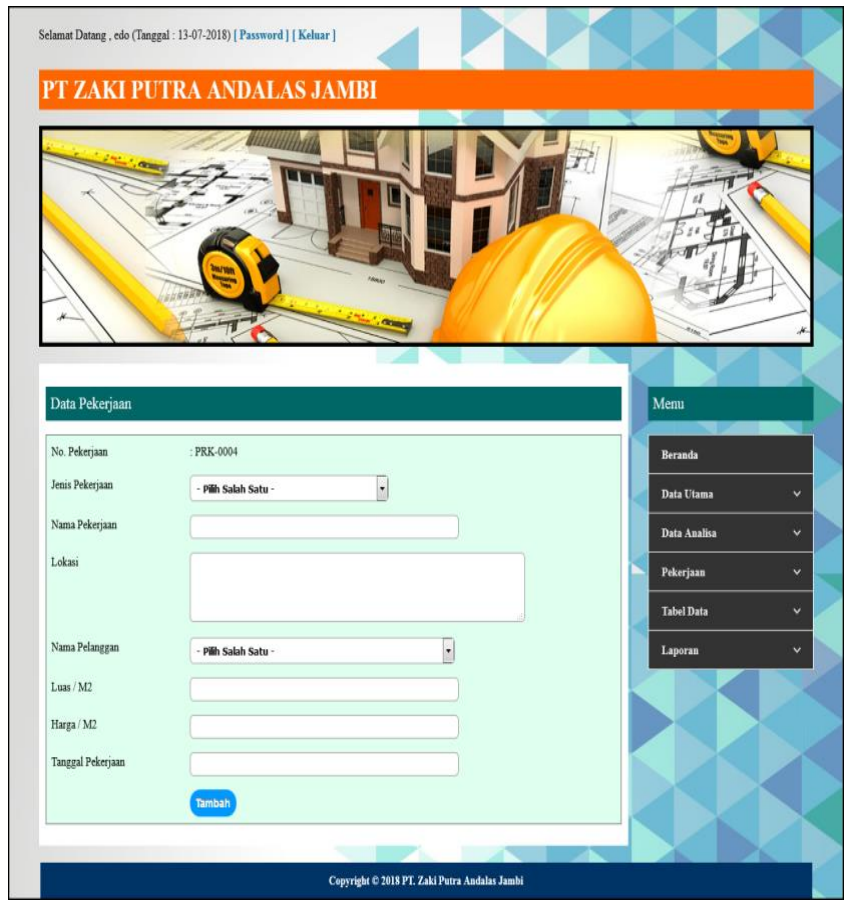

Gambar 10. Data Pekerjaan

8. Halaman Data Rencana Anggaran Biaya

Halaman data rencana anggaran biaya merupakan halaman yang menampilkan kolom-kolom untuk menambah data rencana anggaran biaya yang baru pada sistem.

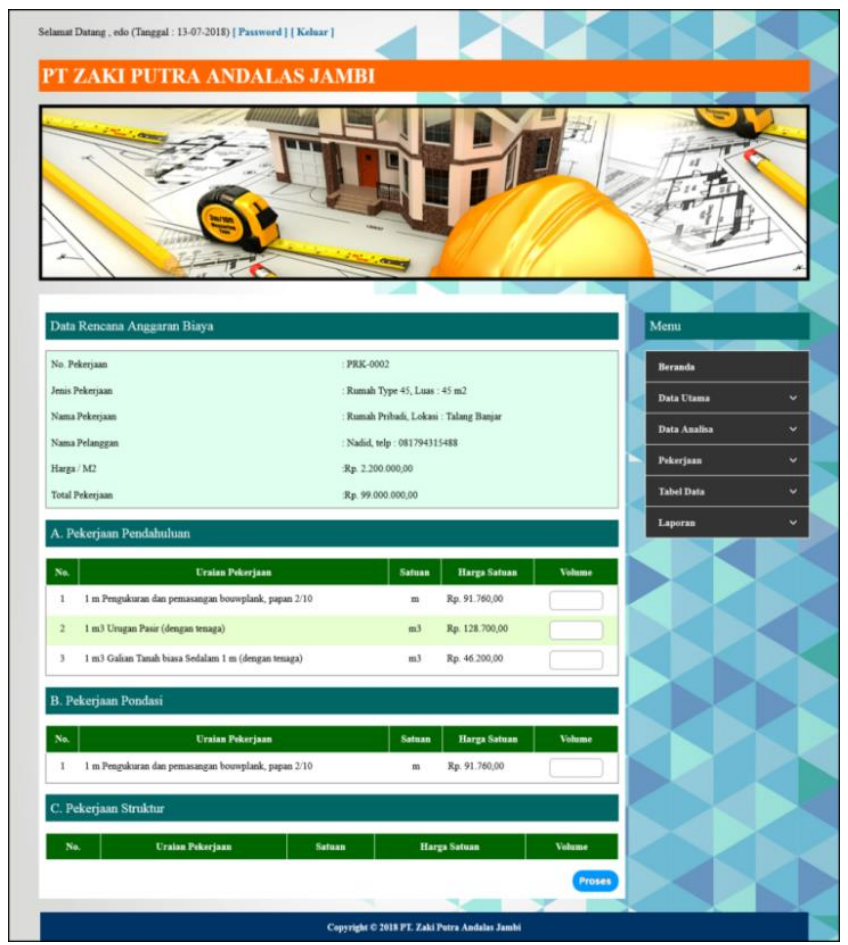

Gambar 11. Data Rencana Anggaran Biaya 
9. Halaman Beranda

Halaman beranda merupakan halaman pertama kali diakses setelah melakukan login dengan menampilkan gambaran umum perusahaan PT. Zaki Putra Andalas Jambi dan menu-menu yang dapat menghubugkan ke halaman lainnya.

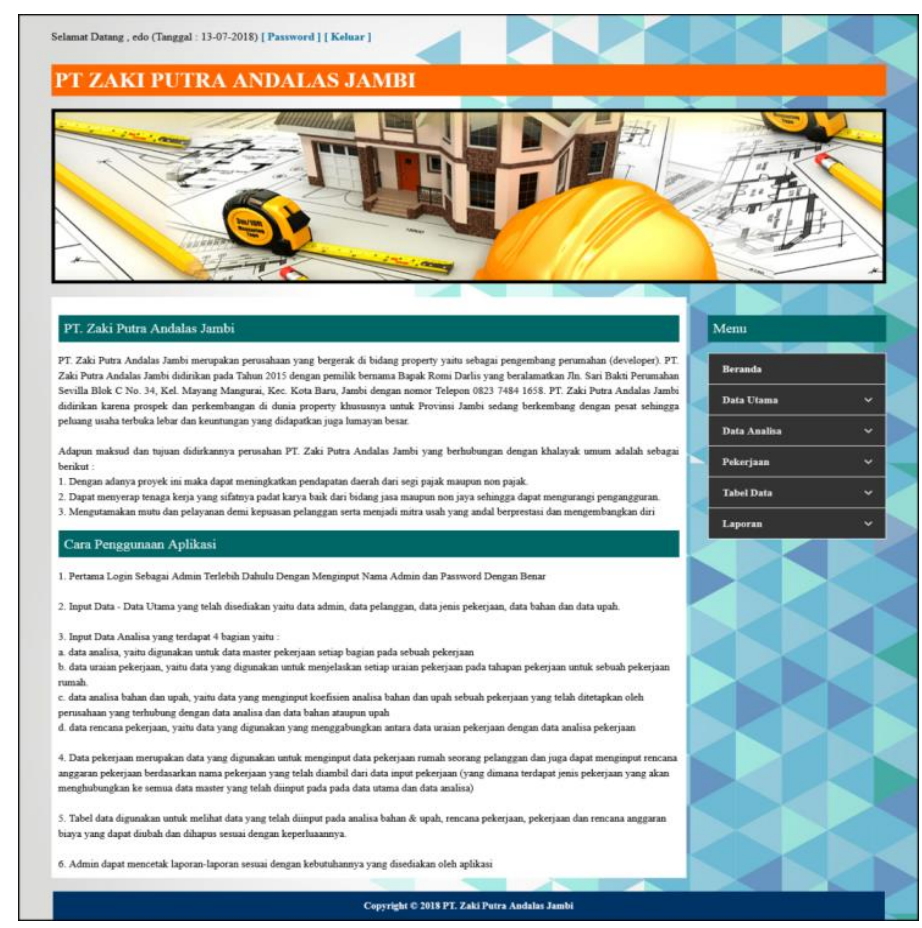

Gambar 12. Beranda

10. Halaman Laporan Analisa Bahan \& Upah

Halaman laporan analisa bahan \& upah merupakan halaman yang menampilkan informasi bahan \& upah dan terdapat tombol untuk mencetak laporan tersebut.

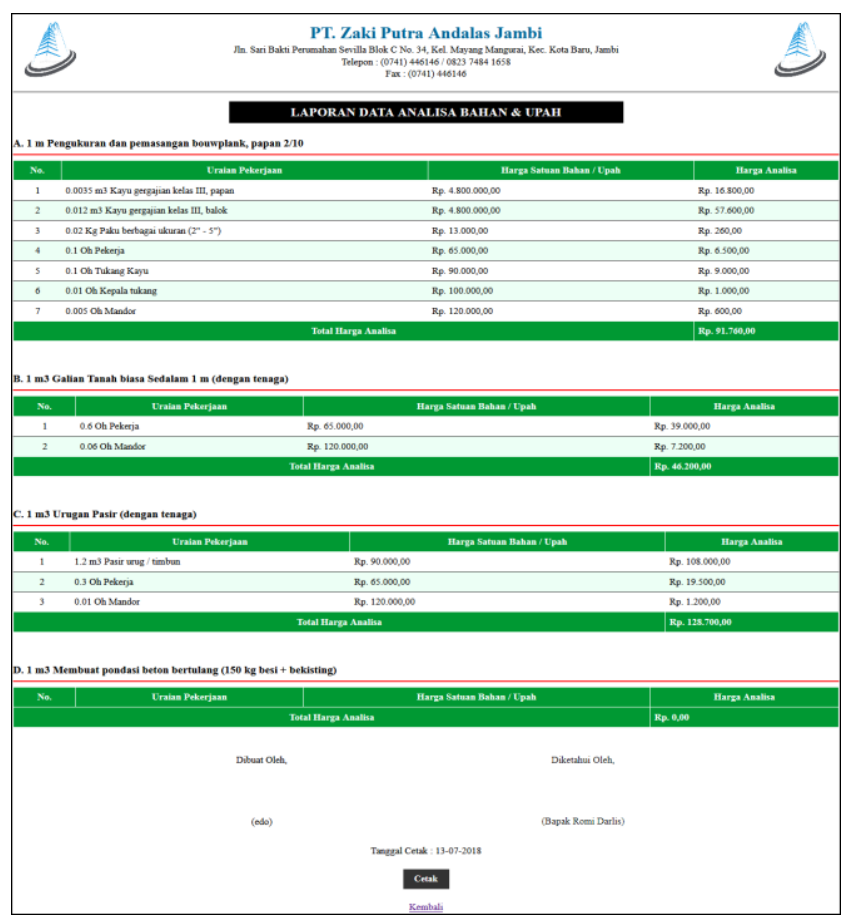

Gambar 13. Laporan Analisa Bahan \& Upah 
11. Halaman Laporan Rencana Pekerjaan

Halaman laporan rencana pekerjaan merupakan halaman yang menampilkan informasi rencana pekerjaan dan terdapat tombol untuk mencetak laporan tersebut.

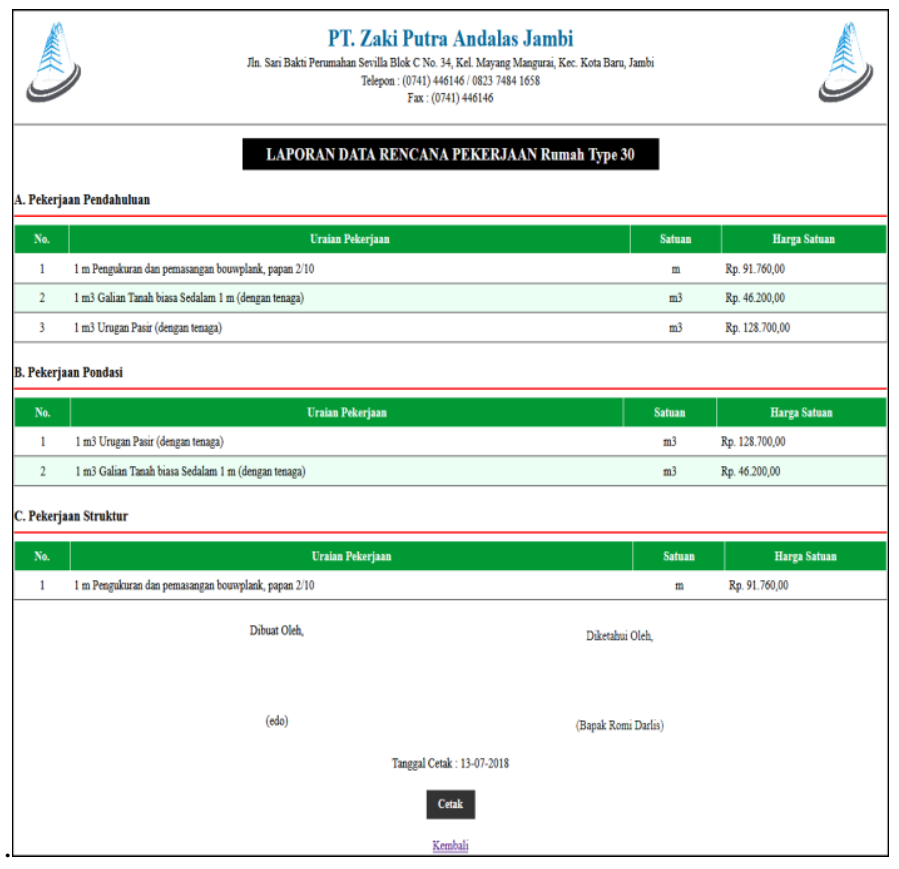

Gambar 14. Laporan Rencana Pekerjaan

12. Halaman Laporan Rencana Anggaran Biaya

Halaman laporan rencana anggaran biaya merupakan halaman yang menampilkan informasi rencana anggaran biaya dan terdapat tombol untuk mencetak laporan tersebut.

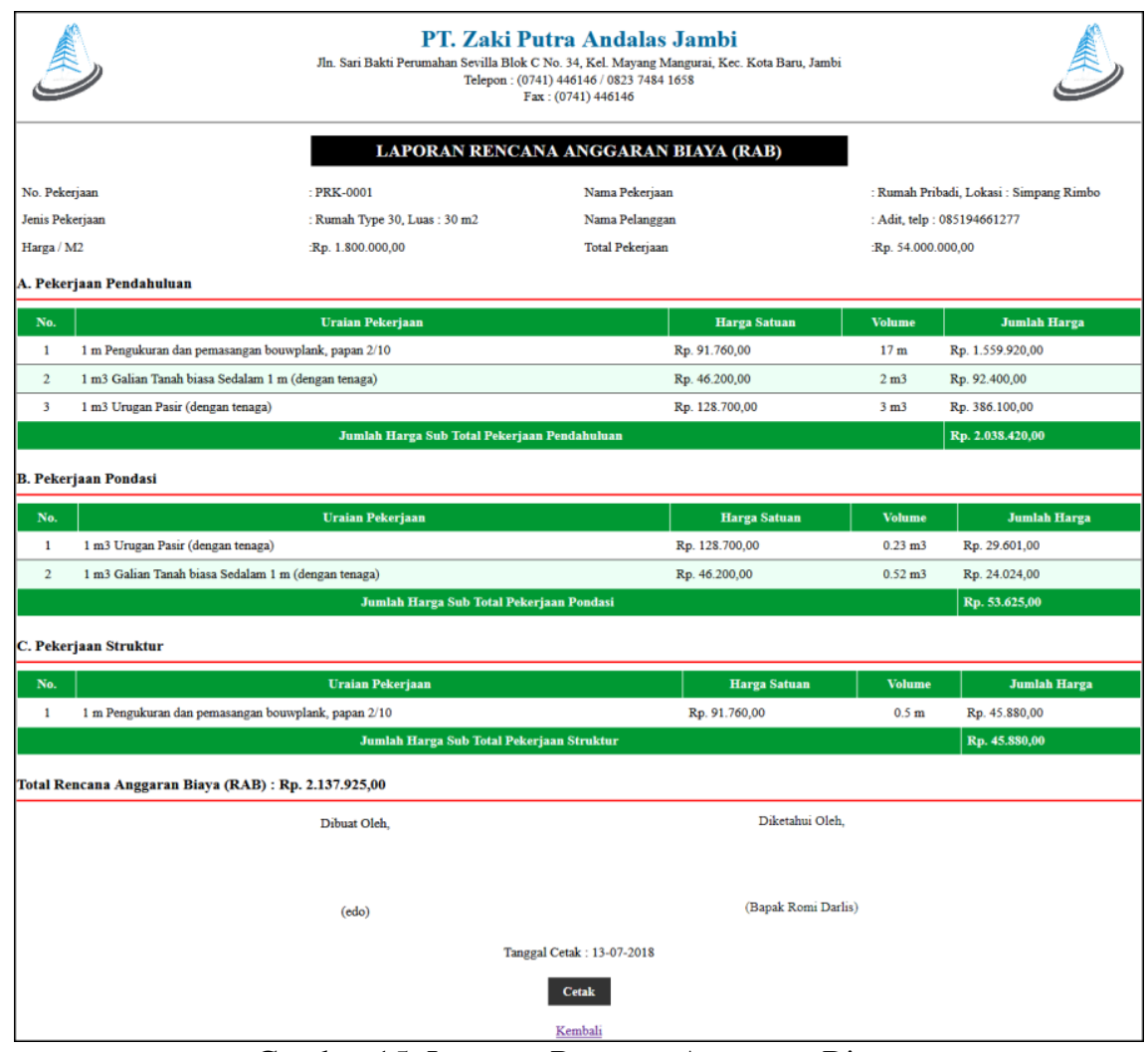

Gambar 15. Laporan Rencana Anggaran Biaya 


\section{Kesimpulan}

Sistem informasi perhitungan rencangan anggaran biaya (RAB) pada PT. Zaki Putra Andalas Jambi dapat membantu mengolah data menjadi lebih mudah, terarah dan bermanfaat dalam mengurangi resiko terjadinya kesalahan dalam pengolahan data dan membantu meningkatkan kinerja dan pembuatan laporan serta memudahkan karyawan dalam membuat RAB. Sistem informasi ini menyediakan fitur dapat melakukan pengolahan data secara terkomputerisasi baik menambah, mengubah dan menghapus data, dapat melakukan pencarian data sesuai dengan tanggal, dan penyimpanan data menggunakan database MySQL sehingga dapat menyimpan lebih aman dan terorganisir dengan baik. Serta memudahkan pengguna sistem dalam merekap dan mencetak laporan-laporan yang diserahkan kepada pimpinan perusahaan.

\section{Daftar Rujukan}

[1] D. P. E. Sembiring, "Perancangan Aplikasi Perhitungan Rencana Anggaran Biaya (RAB) Pembangunan Rumah Dengan Metode Burgerlijkeopenbare Werken ( BoW )," Pelita Inform. Budi Darma, vol. XVI, no. 1, pp. 16-20, 2017.

[2] M. M. Pontoh et al., "Aplikasi Rekayasa Nilai Pada Proyek Konstruksi Perumahan ( Studi Kasus Perumahan Taman Sari Metropolitan Manado Pt. Wika Realty )," J. Tek. Sipil, vol. 1, no. 5, pp. 328-334, 2013.

[3] E. Gardjito, "Pengendalian Jadwal Dan Anggaran Terpadu Dengan Metode Earned Value Analysis Pada Pekerjaan Konstruksi," UKaRst, vol. 1, no. 1, pp. 47-62, 2017.

[4] A. Kartika, and Irwinsyah, "Aplikasi Akuntansi Anggaran Belanja Dan Realisasi Pada Madrasah Aliyah Al-Hikmah Bandar Lampung," J. Sist. Inf. Akunt. AMIK Dian Cipta Cendikia, vol. 2, no. 1, pp. 9-14, 2019.

[5] Indrajani, Perancangan Basis Data Dalam All In 1. Jakarta: PT. Elex Media Komputindo, 2015.

[6] A. Y. A. Firmansyah, A. P. Widodo and A. Sukmaaji, "Rancang Bangun Aplikasi Rencana Anggaran Biaya Dalam Pembangunan Rumah," STIKOM Surabaya, 2014.

[7] D. Rahmadini and R. Vitriani, "Sistem Informasi Rencana Anggaran Biaya Pembangunan Jaringan Terdistribusi Pada Pt. Cipta Aparta ”Jurnal Sains dan Informatika, Vol 2 No 1, 2016.

[8] R. Fajri and R. Arni, "Model Sistem Informasi Pencatatan Pengembangan Bangunan Gedung," $J$. PROGRESIF, Volume 11 No. 1, 2015.

[9] A. Nugroho, Y. R. Beeh, and H. Astuningdyas, "Perancangan Aplikasi Rencana Anggaran Biaya (RAB) (Studi Kasus Pada Dinas Pekerjaan Umum Kota Salatiga).," Jurnal Informatika., vol. 10, no. $1,2009$.

[10] M. R. Hidayat, A. P. Widodo and Ayuningtyas, "Rancang Bangun Aplikasi Analisis Laporan Realisasi Anggaran Pembangunan Gedung mengacu Pada Standar Nasional Indonesia (Studi Kasus: CV. Citra Mandiri Solution)," J. JSIKA, vol. Vol 3 No.1, 2014. 